Published by Al-Nahrain College of Medicine P-ISSN 1681-6579

E-ISSN 2224-4719

Email: iraqijms@colmed-alnahrain.edu.iq

http://www.colmed-alnahrain.edu.iq

http://www.iraqijms.net

Iraqi JMS 2019; Vol. 17(1)

\title{
Risk Factors of Chronic Kidney Disease among Patients Attending Ibn Sina Teaching Hospital in Mosul City
}

\author{
Fanar F. Khaleel ${ }^{1}$ FABHS/ Family Medicine, Shaima S. Hussain ${ }^{2}$ FICSM/Family Medicine, Azzam H. \\ Hmood $^{3}$ FICSM/Family Medicine
}

${ }^{1}$ University Primary Health Care Center, Mosul, Iraq, ${ }^{2} \mathrm{Al}$-Qudis Primary Health Care Center, Mosul, Iraq, ${ }^{3} \mathrm{Ibn}$-Sina

Teaching Hospital, Mosul, Iraq

\begin{abstract}
Background Chronic kidney disease (CKD) is a long-term health condition that in many cases is preventable. Many people do not know they have kidney disease, because up to $90 \%$ of kidney function can be lost before symptoms are evident. Fortunately, simple tests performed by a general practitioner can identify most cases of CKD when the disease is in its early stages, enabling treatment to prevent or slow progress.

Objective To evaluate the risk factors for the development of CKD.

Methods

A case-control study conducted to 300 persons (150 cases and 150 controls) selected from Medical Wards, Dialysis Kidney Unit and in Outpatient Clinic at Ibn Sina Teaching Hospital in Mosul City.

Results Diabetes mellitus (DM) had 12.9 folds risk for developing of CKD and both type 1 and type 2 D.M. had significant role for developing CKD. Diabetic patients for (> 15 years) had 29.8 times risk for development of CKD. Hypertension (HT) had 3.5 folds risk for CKD and those having HT more than 15 years had 12.9 times risk for CKD. Cardiovascular disease (CVD) had 13.6 folds risk for CKD and having more than one type of CVD had 37 times risk for CKD than heart failure, ischemic heart disease. Family history of renal diseases had 7.1 times risk for CKD and there was statistically significant role of having family history of CKD that had more than 22 times risk for CKD. Statistically significant role of having proteinuria with 383 times risk for CKD.

Conclusion There are many risk factors significantly contributing to the development of CKD in Mosul especially DM, HT, CVD, family history of renal disease, family history of chronic diseases, and from this study it has been concluded that proteinuria plays a major role for the development and progress of CKD.

Keywords Chronic kidney disease, risk factors

Citation

Khaleel FF, Hussain SS, Hmood AH. Risk factors of chronic kidney disease among patients attending Ibn Sina Teaching Hospital in Mosul City. Iraqi JMS. 2019; 17(1): 24-31. doi: 10.22578/IJMS.17.1.5
\end{abstract}

List of abbreviations: ACEI = Angiotensin converting enzyme inhibitor, $A K I=$ Acute kidney injury, $A R B=$ Angiotensin receptor blocker, $\mathrm{BPH}=$ Benign prostatic hyperplasia, $\mathrm{CAD}=$ Coronary artery disease, $\mathrm{CKD}$ $=$ Chronic kidney disease, NSAID $=$ Non-steroidal anti-inflammatory drugs, RA = Rheumatoid arthritis, SLE = Systemic lupus erythematosus, UTI = Urinary tract infection

\section{Introduction}

hronic kidney disease (CKD) refers to all conditions of the kidney, lasting more than three months, where a person has had evidence of kidney damage and/or reduced kidney function. Evidence of kidney damage manifests as either proteinuria or albuminuria, hematuria or scarring detected by imaging tests (1,2) (Table 1).

KDOQI guidelines have classified CKD into five stages (Table 2). 
Table 1. Criteria for definition of chronic kidney disease (3)

\section{CKD is defined as abnormalities of kidney structure or function, present for more than $\mathbf{3}$ months, with implications for health.}

These may include the following:

\begin{tabular}{|c|c|c|}
\hline \multirow{6}{*}{ Markers of kidney damage } & $\%$ & $\begin{array}{l}\text { Albuminuria (Alb. Excretion Rate } \geq 30 \mathrm{mg} / 24 \mathrm{~h} \text {; Alb. To } \\
\text { Creatinine Ratio } \geq 30 \mathrm{mg} / \mathrm{g} \text { ( } \geq 3 \mathrm{mg} / \mathrm{mmol} \text { ) }\end{array}$ \\
\hline & 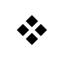 & Urine sediment abnormalities (Pyuria, haematuria, cast) \\
\hline & $*$ & $\begin{array}{l}\text { Electrolyte and other abnormalities caused by tubular } \\
\text { disorders }\end{array}$ \\
\hline & $*$ & Abnormalities detected through histology \\
\hline & $*$ & Structural abnormalities detected through imaging \\
\hline & 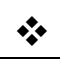 & History of kidney transplantation \\
\hline $\begin{array}{l}\text { Decreased GFR (Glomerular } \\
\text { Filtration Rate) }\end{array}$ & & $\mathrm{GFR}<60 \mathrm{ml} / \mathrm{min} / 1.73 \mathrm{~m}^{2}$ \\
\hline
\end{tabular}

Table 2. Stages of chronic kidney disease based on estimated glomerular filtration rate ${ }^{(3,4)}$

\begin{tabular}{|c|c|c|}
\hline $\begin{array}{c}\text { eGFR } \\
\left(\mathrm{mL} / \mathrm{min} / 1.73 \mathrm{~m}^{2}\right) \\
\end{array}$ & Description & Clinical Action Plan \\
\hline 90 & $\begin{array}{l}\text { Stage } 1 \text { CKD - } \\
\text { Kidney damage } \\
\text { with normal kidney } \\
\text { function }\end{array}$ & $\begin{array}{l}\text { Establish etiology of CKD } \\
\text { Diagnose and treat cardio vascular disease (CVD) } \\
\text { risk factors and comorbid conditions }\end{array}$ \\
\hline $60-89$ & $\begin{array}{l}\text { Stage } 2 \text { CKD - } \\
\text { Kidney damage } \\
\text { with mild decrease } \\
\text { in kidney function }\end{array}$ & $\begin{array}{l}\text { Estimate CKD progression rate } \\
\text { Diagnose and treat CVD risk factors and comorbid } \\
\text { conditions }\end{array}$ \\
\hline $45-59$ & $\begin{array}{l}\text { Stage 3a CKD - } \\
\text { mild-moderate } \\
\text { decrease in kidney } \\
\text { function }\end{array}$ & $\begin{array}{l}\text { As above, plus: } \\
\text { Kidney imaging study, e.g., US or CT } \\
\text { Consider nephrology consultation }\end{array}$ \\
\hline $30-44$ & $\begin{array}{l}\text { Stage } 3 b \text { CKD - } \\
\text { moderate-severe } \\
\text { decrease in kidney } \\
\text { function }\end{array}$ & $\begin{array}{l}\text { As above plus: Refer patients with diabetes to } \\
\text { nephrology }\end{array}$ \\
\hline $15-29$ & $\begin{array}{l}\text { Stage } 4 \text { CKD - } \\
\text { severe decrease in } \\
\text { kidney function }\end{array}$ & $\begin{array}{l}\text { Nephrology consultation with transition of } \\
\text { management and care } \\
\text { Initiate decisions regarding kidney replacement } \\
\text { therapy, vascular access, and kidney transplant } \\
\text { Diagnose and treat CVD risk factors and comorbid } \\
\text { conditions } \\
\text { Adjust drug dosing for CKD stage }\end{array}$ \\
\hline$<15$ & $\begin{array}{l}\text { Stage } 5 \text { CKD - } \\
\text { ESKD }\end{array}$ & $\begin{array}{l}\text { As above plus: } \\
\text { Referral to a nephrologist }\end{array}$ \\
\hline
\end{tabular}


The risk factors for progression to CKD are divided into non modifiable \& modifiable factors.

A- Non modifiable risk factors:

- Age (older age)

- Gender (generally worse in males)

- Race or Ethnicity (non-Caucasian)

- Genetics like adult polycystic kidney disease

- Family history of renal disease

- Family history of chronic disease (Diabetes mellitus (DM), hypertenstion (HT), dyslipidemia \& heart disease)

B- Modifiable risk factors:

- Obesity or metabolic syndrome

- Smoking

- Residence

- Low socioeconomic status \& low levels of education

- Diabetes mellitus
- Systemic hypertension

- Cardiovascular disease

- Dyslipidemia

- Nephrotoxic agents: NSAIDs, analgesics, aminoglycosides, ACEI, and radiographic contrast media.

- Autoimmune disease: SLE, RA, vasculitis

- Previous episode of acute renal failure

- Proteinuria

- Abnormal urinary sediment

- Structural abnormalities of the urinary tract

- History of obstructive uropathy (renal stone, $\mathrm{BPH}$, malignancy)

- History of recurrent UTI and pyelonephritis

The progression of CKD is demonstrated in the figure 1.

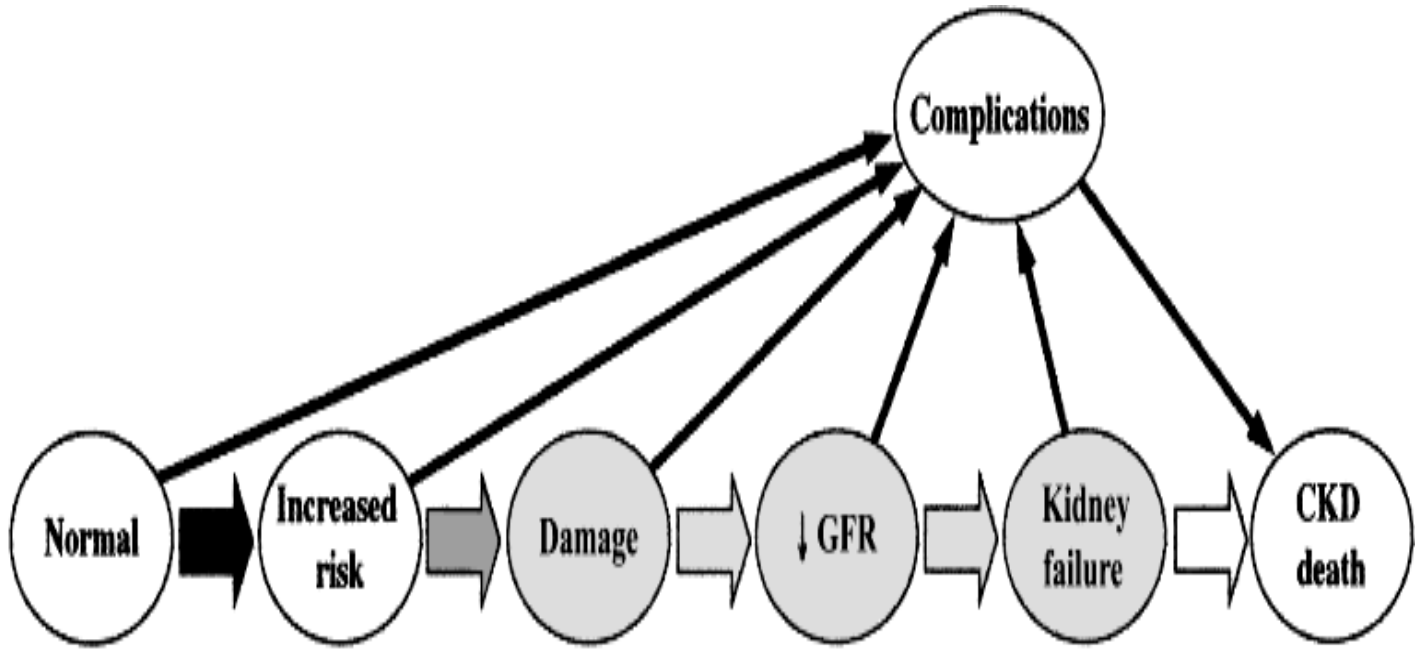

$\begin{array}{ccccc}\begin{array}{c}\text { Screening for CKD } \\ \text { risk factors }\end{array} & \begin{array}{c}\text { CKD risk } \\ \text { redoction, }\end{array} & \begin{array}{c}\text { Diagnosis } \\ \text { \& treatment, }\end{array} & \begin{array}{c}\text { Estimate progression, } \\ \text { Treat complications, }\end{array} & \begin{array}{c}\text { Replacement } \\ \text { by dialysis }\end{array} \\ & \text { Screening for CKD } & \text { Treat comorbid } & \text { Prepare for } & \text { \& transplant } \\ \text { conditions, } & \text { replacement }\end{array}$

Slow progression

Figure 1. Stages in progression of chronic kidney disease and therapeutic strategies ${ }^{(5)}$ 
This study aimed to assess the risk factors that contribute to the development \& progression of CKD.

\section{Methods}

\section{Settings \& study design}

The present study was conducted in the Medical Wards and Dialysis Kidney Unit at Ibn Sina Teaching Hospital in Mosul city. This hospital is located in the right bank of Tigris River and it delivers services to many patients in Mosul city. This hospital has 3 medical wards for male and female adults' patients, each medical ward has 66 beds, also include dialysis kidney unit.

A Case control design was adopted to 300 persons (150 cases and 150 controls) in order to achieve the objective of the present study.

\section{Ethical consideration}

An official agreement was obtained from the Ministry of Health and Directorate of Health in Mosul before conduction of the study. A verbal consent was taken from all the cases and controls included in the study.

\section{Case and control definition}

Case: patient, aged $>18$ years old, admitted to the Medical Wards or Dialysis Kidney Unit at Ibn Sina Teaching Hospital who is a known case of CKD diagnosed by his specialist.

Control: patient, aged $>18$ years old, admitted to the Medical Wards at Ibn Sina Teaching Hospital \& proved that he is not having CKD by estimation of GFR.

Both cases and controls were randomly collected (in a lottery method) during the study period (from $1^{\text {st }}$ of February 2016 to $31^{\text {st }}$ of July 2016).

\section{Inclusion criteria}

Those patients with CKD \& aged $>18$ years old.

\section{Exclusion criteria}

Those with present AKI (Acute kidney Injury).

\section{Retrieving data}

The main source of data was obtained directly from the cases and controls by the investigator through direct interview with the patients, from their case sheets \& from the laboratory results (blood \& urine) of each case or control and filling the questionnaire form which was prepared to record all relevant information related to cases and controls in the study sample.

\section{Procedure:}

The questionnaire form was specially prepared in order to collect all the relevant information related to the study sample. The questionnaire form included information in regard to:

Patient sociodemographic factors, previous history of DM, previous history of HT, previous history of CVD, family history of renal diseases, GUE (general urine examination), blood Urea, serum creatinine, serum total cholesterol, eGFR (estimated GFR).

(This questionnaire information was gathered from multiple recent resources including comprehensive clinical nephrology 2015, Harrison nephrology \& recent researches about CKD).

\section{Analysis of data}

Data were entered to a Word-Excel 2010 worksheet and statistical analysis of data was carried out by using Pentium five computer through the use of (SYSTAT 12) statistical software.

\section{Results}

Table 3 shows that diabetes mellitus has 12.9 risk for developing of CKD and that type 2 has 12.4 risk and more than 15 years of diabetes has 30 risks for developing of CKD. 
Table 3. Distribution of the cases and controls according to diabetes mellitus

\begin{tabular}{|c|c|c|c|c|c|c|c|}
\hline \multirow{2}{*}{ DM } & \multicolumn{2}{|c|}{ Case } & \multicolumn{2}{|c|}{ Control } & \multirow{2}{*}{ O.R. } & \multirow{2}{*}{$\begin{array}{c}\text { P- } \\
\text { Value }\end{array}$} & \multirow{2}{*}{ 95\% of C.I. } \\
\hline & No. & $\%$ & No. & $\%$ & & & \\
\hline Yes & 58 & 38.67 & 7 & 4.0 & \multirow{3}{*}{12.879} & \multirow{3}{*}{0.000} & $5.733-$ \\
\hline No & 92 & 61.33 & 143 & 96.0 & & & 28.857 \\
\hline Total & 150 & 100 & 150 & 100 & & & \\
\hline \multicolumn{8}{|l|}{ Types of DM } \\
\hline Type 1 & 7 & 12.9 & 1 & 14.29 & 7.294 & 0.032 & $\begin{array}{l}1.150- \\
45.872\end{array}$ \\
\hline Type 2 & 51 & 87.93 & 6 & 85.71 & 12.364 & 0.000 & $5.222-29.187$ \\
\hline Total & 58 & 100 & 7 & 100 & & & \\
\hline \multicolumn{8}{|l|}{$\begin{array}{c}\text { Duration of } \\
\text { DM }\end{array}$} \\
\hline$<10$ years & 9 & 15.52 & 4 & 57.14 & 2.330 & 0.156 & $0.742-7.292$ \\
\hline $10-15$ years & 24 & 41.38 & 2 & 28.57 & 14.095 & 0.000 & $\begin{array}{l}3.611- \\
54.726\end{array}$ \\
\hline$>15$ years & 25 & 43.10 & 1 & 14.29 & 29.800 & 0.000 & $\begin{array}{l}5.035- \\
175.33\end{array}$ \\
\hline Total & 58 & 100 & 7 & 100 & & & \\
\hline
\end{tabular}

Table 4 reveals that hypertension has 3.4 risks and having hypertension for more than 15 years has 13 risks for developing of CKD.

Table 5 reveals that CVD has 13.7 risks and having more than one type of CVD has 37.25 risks for developing of CKD.
Table 6 reveals that Family history of renal disease has 7 risks and family history of CKD has 23 risks for developing of CKD.

Table 7 reveals that proteinuria has 383 risks for developing of CKD.

Table 4. Distribution of the cases and controls according to hypertension

\begin{tabular}{cccccccc}
\hline \multirow{2}{*}{ HT } & \multicolumn{2}{c}{ Case } & \multicolumn{2}{c}{ Control } & O.R. & P- & \multirow{2}{*}{ 95\% of C.I. } \\
\hline Yes & 91 & 60.67 & 46 & 30.67 & 3.487 & 0.000 & $2.166-5.613$ \\
No & 59 & 39.33 & 104 & 69.33 & & & \\
Total & 150 & 100 & 150 & 100 & & & \\
\hline $\begin{array}{c}\text { Duration of } \\
\text { HT }\end{array}$ & & & & & & & \\
$<\mathbf{1 0}$ years & 39 & 42.85 & 39 & 85.0 & 1.000 & 1.000 & $0.598-1.671$ \\
$\mathbf{1 0 - 1 5}$ years & 40 & 43.96 & 6 & 13.0 & 8.727 & 0.000 & $3.654-$ \\
& & & & & & & 20.783 \\
$>\mathbf{1 5}$ years & 12 & 13.19 & 1 & 2.0 & 12.96 & 0.002 & $2.124-$ \\
Total & 91 & 100 & 46 & 100 & & & 78.430 \\
\hline
\end{tabular}


Table 5. Distribution of the cases and controls according to cardiovascular disease

\begin{tabular}{|c|c|c|c|c|c|c|c|}
\hline \multirow{2}{*}{ CVD } & \multicolumn{2}{|c|}{ Case } & \multicolumn{2}{|c|}{ Control } & \multirow{2}{*}{ O.R. } & \multirow{2}{*}{$\begin{array}{c}\text { P- } \\
\text { Value }\end{array}$} & \multirow{2}{*}{$95 \%$ of C.I. } \\
\hline & No. & $\%$ & No. & $\%$ & & & \\
\hline Yes & 48 & 31.33 & 5 & 3.33 & \multirow{3}{*}{13.647} & \multirow{3}{*}{0.000} & $5.401-$ \\
\hline No & 102 & 68.67 & 145 & 96.67 & & & 34.370 \\
\hline Total & 150 & 100 & 150 & 100 & & & \\
\hline \multicolumn{8}{|l|}{ Types of CVD } \\
\hline IHD & 11 & 22.9 & 3 & 60.0 & 3.878 & 0.029 & $\begin{array}{l}1.136- \\
13.167\end{array}$ \\
\hline $\mathrm{HF}$ & 7 & 14.5 & 1 & 20.0 & 7.294 & 0.032 & $\begin{array}{l}1.150- \\
45.872\end{array}$ \\
\hline >one type & 30 & 62.5 & 1 & 20.0 & 37.25 & 0.000 & $\begin{array}{l}6.323- \\
218.22\end{array}$ \\
\hline Total & 48 & 100 & 46 & 100 & & & \\
\hline
\end{tabular}

Table 6. Distribution of the cases and controls according to family history of renal diseases

\begin{tabular}{|c|c|c|c|c|c|c|c|}
\hline \multirow{2}{*}{$\begin{array}{c}\text { Family history } \\
\text { of renal } \\
\text { disease }\end{array}$} & \multicolumn{2}{|c|}{ Case } & \multicolumn{2}{|c|}{ Control } & \multirow[b]{2}{*}{ O.R. } & \multirow{2}{*}{$\begin{array}{c}\text { P- } \\
\text { Value }\end{array}$} & \multirow[b]{2}{*}{$95 \%$ of C.I. } \\
\hline & No. & $\%$ & No. & $\%$ & & & \\
\hline Yes & 43 & 28.67 & 8 & 4.67 & \multirow{3}{*}{7.133} & \multirow{3}{*}{0.000} & $3.269-$ \\
\hline No & 107 & 71.33 & 142 & 95.33 & & & 15.527 \\
\hline Total & 150 & 100 & 150 & 100 & & & \\
\hline \multicolumn{8}{|l|}{$\begin{array}{c}\text { Types of } \\
\text { Family history } \\
\text { of renal al } \\
\text { diseases }\end{array}$} \\
\hline $\begin{array}{l}\text { Polycystic } \\
\text { kidney } \\
\text { disease }\end{array}$ & 2 & 4.65 & 1 & 12.5 & 2.014 & 0.562 & $\begin{array}{l}0.260- \\
15.507\end{array}$ \\
\hline CKD & 20 & 46.51 & 1 & 12.5 & 22.92 & 0.000 & $\begin{array}{l}3.845- \\
135.75\end{array}$ \\
\hline kidney stone & 12 & 27.91 & 5 & 62.5 & 2.522 & 0.080 & $0.900-7.040$ \\
\hline >one type & 9 & 20.93 & 1 & 12.5 & 9.511 & 0.010 & $\begin{array}{l}1.530- \\
58.617\end{array}$ \\
\hline Total & 43 & 100 & 8 & 100 & & & \\
\hline
\end{tabular}

Table 7. Distribution of the cases and controls according to proteinuria

\begin{tabular}{cccccccc}
\hline $\begin{array}{c}\text { Family history } \\
\text { of renal } \\
\text { disease }\end{array}$ & No. & $\%$ & No. & $\%$ & O.R. & $\begin{array}{c}\text { P. } \\
\text { Value }\end{array}$ & 95\% of C.I. \\
\hline Yes & 108 & 72.0 & 1 & 0.67 & 383.143 & 0.000 & $65.202-$ \\
No & 42 & 28.0 & 149 & 99.33 & & & 2231.9 \\
Total & 150 & 100 & 150 & 100 & & & \\
\hline
\end{tabular}


Figure 2 shows that the highest rates of the risk factors of CKD, which had statistically significant association for the developing of CKD were: proteinuria $(72 \%)(P=0.000)$, family history of chronic diseases (68\%) $(P=0.000)$, hypertension $(60.67 \%) \quad(P=0.002)$, urinary cast $(61.33 \%)$ $(P=0.000)$, pyuria $(58.67 \%)(P=0.000)$, cigarettes smoking (50\%) ( $\mathrm{P}=0.000)$, dyslipidemia (46\%) $(P=0.000)$ and showed that hematuria, recurrent pyelonephritis and illiterate had (43.30\%) ( $P=0.000)$ and for $\operatorname{DM~(38.7\% )~}$ $(P=0.000)$ and for Nephrotoxic drugs and agents (34.67\%) $(P=0.000)$.

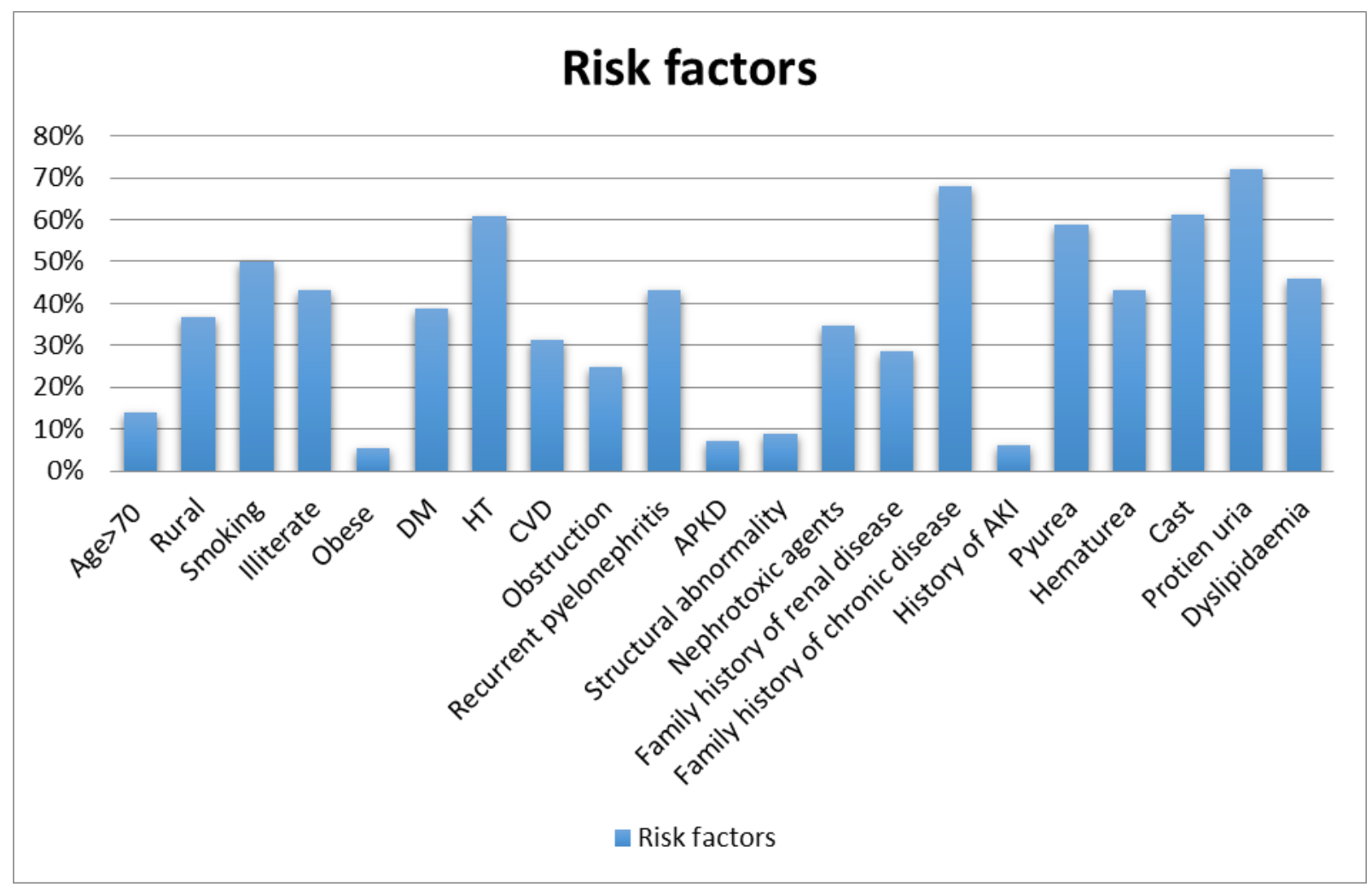

Figure 2. Distributions of the rates of the risk factors of CKD in the case group

\section{Discussion}

From this study it has been revealed that diabetes has $38.67 \%$ of the adult cases with CKD. Nevertheless, $20-40 \%$ of diabetics will develop diabetic nephropathy during the end stage of their disease; therefore, with the increase of cases of diabetic patients, the incidence of CKD is expected to rise. This result was similar to the result of the study done in 2003 (and to the result in the study by Remuzzi et al in $2012^{(6)}$. Hypertension is very common in patients with CKD, and the level of blood pressure is associated with the rate of loss of kidney function. Control of blood pressure slows the rate of decline of kidney function. This result was similar to the result of the study in $2016^{(7)}$. The presence of CVD like IHD (ischemic heart disease) and HF (heart failure) is independently associated with kidney function decline, increased risks of serum creatinine elevation, eGFR decline and development of CKD. This result was similar to the result of a study in united states in $2005{ }^{\text {(8) }}$. Family history of CKD/ESRD has been considered a significant risk factor for CKD. Genetic predisposition plays a key role in many forms of CKD. This result was similar to the result of the study done in Beijing $2008{ }^{~(9) . ~ P r o t e i n u r i a ~ i s ~ t h e ~ s t r o n g e s t ~ s i n g l e ~}$ predictor of GFR decline. Therapies that decrease proteinuria generally slow GFR 
decline. Proteinuria-induced glomerular and renal tubular injury is a key mechanism of natural progression. The threshold for natural progression attributable to proteinuria appears to be crossed when proteinuria exceeds 500 $\mathrm{mg} /$ day. Proteinuria magnitude is the strongest single risk factor CKD progression. This result was similar to the result of a study in $2003{ }^{(5)}$.

This study concluded that there are many risk factors significantly contributing to the development of CKD in Mosul especially diabetes mellitus, hypertension, family history of renal disease, from this study it has been also concluded that proteinuria plays a major role for the development and progression of CKD. Application of further prevention and control are highly recommended to reduce the burden of CKD.

\section{Acknowledgments}

Authors great thanks and appreciation are to all the doctors, medical staffs and parastaffs in Medical Wards and Dialysis Kidney Unit at Ibnsina Teaching Hospital where data were collected, for their cooperation and assistance during data collection.

Also, authors are very grateful to all the patients and their relatives that admitted to Medical Wards and Dialysis Kidney Unit at Ibn-sina Teaching Hospital that included in the study for their kind cooperation, which made this work possible.

\section{Author contribution}

Dr. Khaleel: collection of data, statistics and conclusion. Dr. Hussain: helped in the collection of data. Dr. Hmood: helped by giving clinical notes in collecting the data of the study.

\section{Conflict of interest}

There is financial conflict in doing the investigation for the study and collecting of data.
Funding

Self-funding.

\section{References}

1. National Kidney Foundation. KDOQI clinical practice guidelines for chronic kidney disease: Evaluation, classification, and stratification. Am J Kidney Dis. 2012; 39(suppl 1): S1-S266.

2. Coresh J, Astor BC, Greene T, et al. Prevalence of chronic kidney disease and decreased kidney function in the adult U.S. population: Third National Health and Nutrition Examination Survey. Am J Kidney Dis. 2003; 41(1): 1-12. doi: 10.1053/ajkd.2003.50007

3. Carroll LE. The stages of chronic kidney disease and the estimated glomerular filtration rate. J Lancaster Gen Hosp. 2016; 1: 70-74.

4. Caskey F, Davenport A, Dawnay A, et al. UK renal registry 2013 16th annual report of the renal association," Nephron Clin Pract. 2013; 125: 1-4.

5. Writing Team for the Diabetes Control and Complications Trial/Epidemiology of Diabetes Interventions and Complications Research Group. Sustained effect of intensive treatment of type 1 diabetes mellitus on development and progression of diabetic nephropathy: the Epidemiology of Diabetes Interventions and Complications (EDIC) study. JAMA. 2003; 290(16): 2159-67. doi: 10.1001/jama.290.16.2159.

6. Remuzzi G, Schieppati A, Ruggenenti P. Clinical practice. Nephropathy in patients with type 2 diabetes. N Engl J Med. 2012; 346(15): 1145-51. doi: 10.1056/NEJMcp011773.

7. Klag MJ, Whelton PK, Randall BL, et al. Blood pressure and end-stage renal disease in men. $\mathrm{N}$ Engl J Med. 2016; 334: 13-8. doi: 10.1056/NEJM199601043340103.

8. Foley RN, Murray AM, Li S, et al. Chronic kidney disease and the risk for cardiovascular disease, renal replacement, and death in the United States Medicare population, 1998 to 1999. J Am Soc Nephrol. 2005; 16(2): 489-95. doi: 10.1681/ASN.2004030203

9. Zhang $L$, Zhang $P$, Wang $F$, et al. Prevalence and factors associated with CKD: a population study from Beijing. Am J Kidney Dis. 2008; 51(3): 373-84. doi: 10.1053/j.ajkd.2007.11.009.

\footnotetext{
Correspondence to Dr. Fanar F. Khaleel E-mail:mr.photoshop2@gmail.com Received Jun. $21^{\text {st }} 2018$ Accepted Dec. $18^{\text {th }} 2018$
} 